\title{
Numbers and Population Trends of Cory's Shearwater Calonectris diomedea at Selvagem Grande, Northeast Atlantic
}

\author{
José P. Granadeiro ${ }^{1,2}$, Maria P. Dias², Rui Rebelo², \\ Carlos D. Santos ${ }^{2}$ and Paulo Catry 3

\begin{abstract}
${ }^{1}$ Centro de Biologia Ambiental, Departamento de Zoologia e Antropologia (Museu Bocage) Internet: jpgranadeiro@fc.ul.pt
\end{abstract} \\ Museu Nacional de H istória Natural, Rua da Escola Politécnica 58, 1269-102 Lisboa, Portugal \\ ${ }^{2}$ Centro de Biologia Ambiental, Departamento de Biologia Animal \\ Faculdade de Ciências da U niversidade de Lisboa, 1749-016 Lisboa, Portugal \\ ${ }^{3} U$ nidade de Investigação em Eco-Etologia, Instituto Superior de Psicologia Aplicada \\ Rua Jardim do Tabaco 34, 1149-041 Lisboa, Portugal
}

\begin{abstract}
The island of Selvagem Grande holds one of the most important colonies Cory's Shearwater (Calonectris diomedea) in the Atlantic. Historical records suggest a stable population well in excess of 100,000 pairs. A succession of massacres in 1975 and 1976 dramatically reduced this population to less than $10 \%$ of the original numbers. Since 1977 strict protection was enforced and the population started a steady recovery. H owever, between 1995 and 1998 an alarming decline, of more than 13\% of the birds, was reported and concurrently the monitoring work was interrupted. Data from other colonies in the Atlantic and the Mediterranean also indicated significant regional declines, some of which appear to be driven by unsustainable levels of accidental mortality in fishing gear. In order to investigate the persistence of the regressive trend at Selvagem Grande, we carried out a global census of the colony in June 2005. We counted 20,555 occupied nests and estimated the total breeding population at 29,540 pairs. The population still appears to be recovering from the massacres of 1975-1976, at an average rate of about $4.6 \%$ per year over the past 25 years. O ur data reveal that Selvagem Grande now harbors the largest known Cory's Shearwater colony in the World. Results from this study suggest that this population is not, as yet, suffering from unsustainable fisheries-related mortality, which would be reflected in a decline in numbers. This situation contrasts with that of the Mediterranean, where significant mortality in fishing gear has been linked to shearwater population declines. Received 8 N ovember 2005, accepted 25 N ovember 2005.
\end{abstract}

Key words.-Census, fisheries, longlines, population growth, seabirds.

Waterbirds 29(1): 56-60, 2006

Many species of seabirds are currently under threat due to high immature and adult mortality levels from interactions with fishing gear (Brotherset al. 1999; Tasker et al. 2000; BirdL ife International 2004a). H ookbased fisheries in particular have been recognized as a major cause of incidental mortality of pelagic seabirds and are currently identified as the primary reason for the decline of many populations (e.g., Croxall et al. 1990; Weimerskirch et al. 1997; BirdLife International 2004a).

Cory's Shearwaters Cal on ectris diomedea are pelagic seabirds, with all their breeding colonies located in the Mediterranean and the Northeast Atlantic. The population size of the Atlantic subspecies $C$. diomedea borealis is very roughly estimated at $240,000-250,000$ pairs (BirdLife International 2004b). The bulk of this population seems to be concentrated in the archipelagos of Azores and
Madeira (more than $85 \%$ ) and in the Canary islands (ca. 15\%), with a few pairs also breeding at Berlengas, off the Portuguese coast.

In most of the Atlantic locations there has been little monitoring work, and hence the population trends are based on very tentative estimates of the size of breeding populations (BirdLife International 2004b). The colony of Cory's Shearwater at Selvagem Grande is an exception, because it has been surveyed regularly during the course of scientific expeditions since 1980.

There is an abundant historical record of exploitation of Cory's Shearwaters at Selvagem Grande (e.g., Bannerman 1963; Zino 1985). In the beginning of the 1900s, when the island was still privately owned, in excess of 20,000 chicks were collected annually for meat, oil and feathers (Zino 1985), from a population that was crudely estimated at $130,000-150,000$ breeding pairs (Mougin 
and Mougin 2000). In the late 1960s the intense exploitation of chicks had al ready depressed the population numbers, and a few adult birds probably started to be collected along with the chicks. In 1971, the island was classified as a N ature Reserve, but remained without vigilance and effective protection. In 1975 and 1976 a succession of severe massacres by Portuguese and Spanish fishermen decimated thousands of chicks and adults, causing a major population collapse. In September 1976 only 64 chicks could be found on the entire island (Zino 1985), and in 1980 the population was estimated at only 7000 pairs (Mougin and Stahl 1982). After this, permanent wardening and strict protection were enforced. Simultaneously, a regular monitoring scheme was initiated consisting of a global count at a three-year interval.

The census work at Selvagem Grande suggested a relatively steady population growth, at ca. 5\% per year, and in 1995 the population was estimated at 18,100 breeding pairs (Mougin et al. 1996). However, in 1998 the numbers seemed to have dropped to 15,750 breeding pairs (Mougin and Mougin 2000), a reduction of over $13 \%$ in three years. Large population declines of the Mediterranean subspecies C. diomedea diomedea have also been recorded at several locations, mostly due to interactions with fisheries (e.g., Belda and Sanchéz 2001). Such evidence constitute a serious cause for concern in relation to the possibility of significant losses of Cory's Shearwaters in the breeding or in the wintering areas, the later located in the southern Atlantic (e.g., Camphuysen and Van Der Meer 2001).

In this study, the long-term monitoring work at Selvagem Grande was resumed and the trend data re-examined by adding the results of a global count carried out in 2005. Results are interpreted in light of the demographic events occurring in the past.

\section{METHODS}

Selvagem Grande $\left(30^{\circ} 09^{\prime} \mathrm{N}, 15^{\circ} 52^{\prime} \mathrm{W}\right)$ is the largest of the three islands which constitute the Selvagens $\mathrm{Na}$ ture Reserve, and the only that hosts significant numbers of Cory's Shearwaters. The island is located ca. 300 $\mathrm{km}$ south of Madeira island and $160 \mathrm{~km}$ north of the Canary islands (Fig. 1). It consists of a central plateau (with $161.5 \mathrm{ha}$ ), completely surrounded by cliffs. The

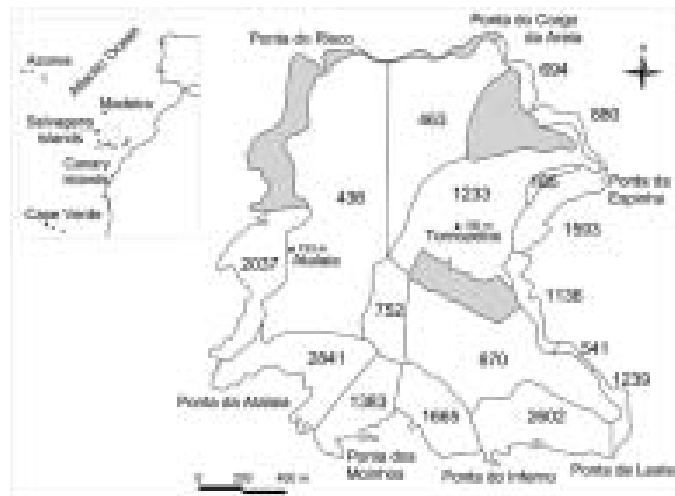

Figure 1. N umber of nests of Cory's Shearwater counted in different sectors of Selvagem G rande. Areas shaded grey were not counted.

area of the cliffs was estimated at $106 \mathrm{ha}$, using digitized elevation data and a Geographical Information System (GIS). The island was divided into 5 large areas following previous census work (e.g., Mougin et al. 1996): north coast, from Ponta do Risco to ponta da Espinha; west coast from Ponta da Espinha down to Ponta de Leste; south coast, from Ponta de Leste to Ponta dos Moinhos; east coast, from Ponta dos Moinhos up to Ponta do Risco, and central plateau (Fig. 1).

Fieldwork was carried out between 15 and 26 June 2005, when all birds had already laid their eggs (Thibault et al. 1997). In order to compare our data with previous census work, we followed the method initially proposed by Mougin and Stahl (1982), which consists of a global count of all nests during the incubation period. The cliff areas and the plateau were sub-divided into large sectors, using natural landmarks. The limits of the sectors were recorded using a GPS (average horizontal accuracy ca. $5 \mathrm{~m}$ ) and subsequently mapped in a GIS.

All sectors were systematically walked by a line of observers, who recorded the number of nests with incubating birds. To the possible extent, cliffs areas were prospected for nests almost from sea-level up to the plateau. O verall, the fieldwork involved ca. 275 man.hours.

The cliffs west from Ponta do Corgo da Areia up to Atalaia are inaccessible (coastal areas, shaded grey in Fig. 1), and were excluded from the census. Also, two sectors of the plateau could not be counted because they hold a dense colony of White-faced storm-petrel Pelagodroma marina, where walking is impossible without trampling the nests (Fig. 1).

At Selvagem Grande, Cory's Shearwaters start to return to land during mid to late afternoon. Hence, our work was carried out before 16:00 h (local time) to avoid counting cavities occupied by prospecting birds.

Some nests could not to be detected, either because they occurred in deep crevices and burrows, where confirmation of breeding was difficult, or because they were located in inaccessible areas. Based on previous experience (Mougin et al. 1994, 1996) this fraction was tentatively estimated at $15 \%$. Also, by the time of our census some birds had already lost their eggs and abandoned the nest sites. Previous work at Selvagem Grande estimated egg loss during incubation at 32\% (M ougin et al. 1994). Counts were carried in the early stage of incubation, when most eggs disappear and therefore we as- 
sumed that $25 \%$ of the clutches had already been lost. Throughout the text, means are presented \pm standard errors.

\section{RESULTS}

O verall, we counted 20,555 nests with an incubating bird. Based on the estimated proportion of eggs lost ( $25 \%)$ and on the fraction located in non-surveyed areas (15\%), the breeding population was estimated at 29,540 pairs. This represents an average increase of $9.5 \%$ per year in relation to the 1998 census ( 15,750 pairs; M ougin and M ougin 2000$)$ and $5.1 \%$ per year in relation to numbers estimated in 1995 (18,000 pairs; Mougin et al. 1996).

Over $80 \%$ of nests were located in cliff sectors, where the overall nest density was $283.0 \pm 57.0$ birds.ha ( $n=11$ sectors). Average densities in the plateau were much lower ( $57.2 \pm 21.5$ birds/ ha, $\mathrm{n}=6$ sectors), with fewer nests in the rather bare NW half of the island in comparison to the SE portion (Fig. 1). On the plateau, nests were located under vegetation (mostly Suaeda vera), in holes excavated on the ground, in abandoned rabbit holes, in natural rocky crevices or in manmade walls.

The analysis of previous count data (Fig. 2) suggests that the south and east coasts have been increasing at a slightly faster rate (6.1\% per year) than the remaining areas ( $4.3 \%$ per year; Fig. 2 ). Based on all the available count data (Mougin and Mougin 2000

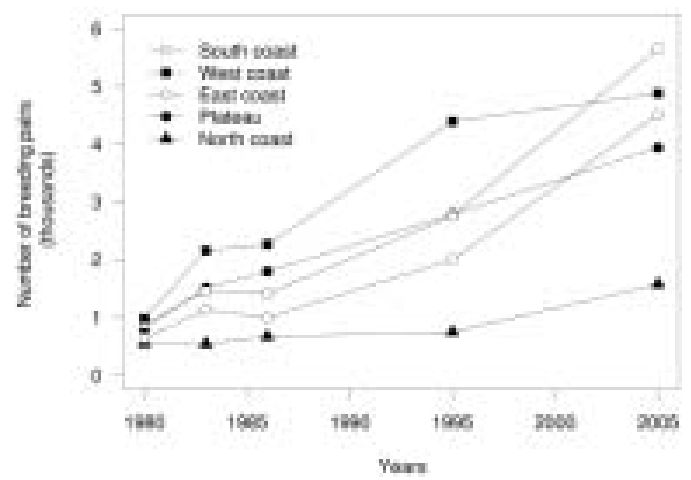

Figure 2. Variation in number of nests of Cory's Shearwater counted in different parts of the Selvagem G rande. Data from 1980 to 1995 obtained from Mougin et al. (1996), and references therein. and references therein), the average growth rate between 1980 and 2005 was estimated at $4.6 \%$ per year.

\section{DISCUSSION}

This study confirms Selvagem Grande to be the largest known breeding colony of Cory's Shearwater in the world, and hence of major importance for the conservation of this species. Selvagem Grande is also the only site in the Atlantic where a large population can be monitored with reasonable accuracy by counting nesting birds, which might prove essential to the global monitoring of this species. Although this colony might not be representative of the global trends in the Atlantic islands, the current data constitutes, as far as we know, the only evidence that C. d. borealis might, as yet, not be suffering from a fisheries-related mortality severe enough to depress population numbers.

O ur study and the available historical data suggest that the population is still recovering from the depredations of 1975-1976. Following these events, ( 1980 to 1985), the numbers built up rapidly, at ca. 30\% per year (Mougin et al. 2000). This rapid increase was due to the progressive recruitment of large numbers of non-breeding birds. These non-breeders were at sea during the massacres ( the average age of first breeding is 9 years old; Mougin et al. 2000), hence they escaped the culling. From 1985 to 1995, the population growth stabilized at an average rate of $5 \%$ per year (M ougin et al. 1996). The apparent decline in numbers indicated by the count in 1998, lead Mougin and Mougin (2000) to infer the onset of a period of stagnation in the population growth. H owever, our results do not seem to support this hypothesis. The present data suggest a population around 30,000 breeding pairs, from which we estimated an average annual growth of $4.6 \%$ since 1980 . Would the overall rate of population growth be maintained at $5 \%$, it would take another 35 years for the population to reach the numbers presumed to exist prior to the massacre (ca. 140,000 pairs).

The strongest recruitment appears to be occurring in the south and east coasts, while 
numbersin the north coast have increased at a lower rate over the years. The northern coast has the most steep cliffs, with less natural cavities and so possibly offer poorer breeding conditions.

The sustained growth observed at Selvagem Grande seems to be at variance with information from colonies elsewhere in Europe. The quality of the trend data is generally poor, but they suggest a decrease or at best a stabilization of the breeding numbers. The Atlantic race $\mathrm{C}$. diomedea borealis has decreased in the Canary islands, and it is currently classified as Vulnerable in Spain (Madroño et al. 2004). In Madeira island the numbers appear to be stable (Cabral et al. in press), but there are no detailed censuses in this area. In the Azores, land-based census of birds forming "rafts" at sea indicated a reduction of over $40 \%$ in numbers in relation to previous counts (Bolton 2001). This large variation in numbers may represent a shift in the foraging areas, rather than a true reduction in the breeding population, but nonetheless it is a cause for concern and highlights the need for further research. The western Mediterranean subspecies Calonectris diomedea diomedea also seems to be suffering large declines mostly due to long-lines (Cooper et al. 2000; Valeiras and Camiñas 2000; Belda and Sánchez 2001), and thus it is classified as Endangered according to the Spanish Red Data Book (Madroño et al. 2004).

Although long-lining has not been identified as a major problem around the breeding areas in the Atlantic, it is certainly a potential threat at their wintering grounds, mostly located along the coasts of South Africa and South America (Mougin et al. 1988; Camphuysen and Van der Meer 2001). It is therefore very important to maintain regular monitoring at the most important breeding locations, for accurate and objective estimation of population trends and early detection of population declines.

\section{ACKNOWLEDGMENTS}

Thanks are due to the services of Parque Natural da Madeira for granting permission to work in Selvagem Grande. We also thank Paulo Oliveira for his kind hospitality and help with the logistics, and Basilio for mak- ing our stay at the island so enjoyable. This study is an output from a project on the ecology of Cory's Shearwaters (POCTI/MAR/ 58778/ 2004) supported by Fundação para a Ciência e a Tecnologia (FCT-Portugal). J. P. Granadeiro and P. Catry benefited from postdoctoral fellowships from FCT (BPD/ 11544/ 02 and BPD/ 11631/ 02)

\section{LITERATURE CITED}

Bannerman, D. A. 1963. Birds of the Atlantic Islands, Vol. I. Oliver \& Boyd, Edinburgh \& London.

Belda, E. J. and A. Sánchez. 2001. Seabird mortality on Iongline fisheries in the western Mediterranean: factors affecting bycatch and proposed mitigation measures. Biological Conservation 98: 357-363.

BirdL ife International. 2004a. Threatened Birds of the World 2004. CD-ROM. BirdLife International, Cambridge.

BirdL ife International. 2004b. Birds in Europe: population estimates, trends and conservation status. BirdLife International, Cambridge.

Bolton, M. 2001. Censo de Cagarro Calon ectris diomedea no Arquipélago dos Açores, 2001. Unpublished Final Report, Department of O ceanography and Fisheries, University of Azores.

Brothers, N. P., J. Cooper and S. Løkkeborg. 1999. The incidental catch of seabirds by longline fisheries: worldwide review and technical guidelines for mitigation. FAO Fisheries Circular. No. 937. Rome.

Cabral M. .. J. Almeida, P.R. Almeida, T. Dellinger, N. Ferrand de Almeida, M. E. Oliveira, J. M. Palmeirim, A. I. Queiroz, L. Rogado and M. Santos-Reis (Eds.). In press. Livro Vermelho dos Vertebrados de Portugal. Instituto da Conservação da Natureza, Lisbon.

Camphuysen, C. J. and J. Van Der Meer. 2001. Pelagic distribution, moult and (sub) specific status of Cory's Shearwaters Calon ectris [d.] diomedea/borealis wintering off southern Africa. Marine Ornithology 29: 89-96.

Cooper, J., J. J. Borg, J. Belda, C. Papaconstantinou and A. Sánchez. 2000. Seabird mortality from longline fishing in the Mediterranean Sea and Macaronesian waters: a review and a way forward. Sciencia Marina 67: 57-64.

Croxall, J. P., P. Rothery, S. P. C. Pickering and P. A. Prince. 1990. Reproductive performance, recruitment and survival of Wandering al batrosses Diomedea exulans at Bird I sland, South Georgia. Journal of Animal Ecology 59: 775-796.

Madroño, A., C. González and J. C. Atienza. 2004. Libro rojo de las aves de España. Ministerio de Medio Ambiente y Sociedad Española de Ornitología (SEO BirdLife), Madrid.

Mougin, J.-L. and M.-C. Mougin. 2000. L'evolution des effectifs des Puffin cendrés Calon ectris diomedea borealis de l'ile Selvagem Grande ( $30^{\circ} 09^{\prime} \mathrm{N}, 15^{\circ} 52^{\prime} \mathrm{W}$ ) de 1995 à 1998. Boletim do Museu Municipal do Funchal 52: 45-50.

Mougin, J.-L. and J.-C. Stahl. 1982. Essai de dénombrement des Puffin cendrés Calonectris diomedea borealis de l'ile Selvagem Grande ( $30^{\circ} 09^{\prime} \mathrm{N}, 15^{\circ} 52^{\prime} \mathrm{W}$ ) en 1980. Museu Municipal do Funchal, Bocagiana 63: $1-17$.

Mougin, J. L., C. Jouanin and F. Roux. 1988. Les migrations du Puffin cendré Calon ectris diomedea. L'O iseau et la Révue Française d'O rnithologie 58: 303-319. 
Mougin, J.-L., J. P. Granadeiro and F. Roux. 1994. L'evolution des effectifs des Puffin cendrés Calonectris diomedea borealis de l'ile Selvagem Grande $\left(30^{\circ} 09^{\prime} \mathrm{N}\right.$, $15^{\circ} 52^{\prime}$ W) de 1989 à 1992 . Boletim do Museu Municipal do Funchal 46: 77-84.

Mougin, J.-L., J. P. Granadeiro and P. Oliveira. 1996. L'evolution des effectifs des reproducteurs chez le Puffin cendrés Calonectris diomedea borealis de Selvagem Grande (3009'N, 1552'W) de 1992 à 1995. Boletim do Museu Municipal do Funchal 48: 171-178.

Mougin, J.-L., C. Jouanin and F. Roux. 2000. Démographie du Puffin cendré de I' ile Selvagem Grande $\left(30^{\circ} 09^{\prime} \mathrm{N}, 15^{\circ} 52^{\prime} \mathrm{W}\right)$. Revue d'Écologie 55: 275-290.

Tasker, M. L., C. J. Camphuysen, J. Cooper, S. Garthe, W. A. Montevecchi and S. J. M. Blaber. 2000. The impacts of fishing on marine birds. ICES J ournal of Marine Science 57: 531-547.
Thibault, J.-C., V. Bretagnolle and C. Rabouam. 1997. Calonectris diomedea Cory's Shearwater. Birds of the Western Palaearctic U pdate 1: 75-98.

Valeiras, J. and J. A. Camiñas. 2000. Incidental captures of sea birds by drifting logline fisheries in Western Mediterranean Sea. Sciencia Marina 67: 65-68.

Weimerskirch, H., N. Brothers and P. Jouventin. 1997. Population dynamics of Wandering Albatross, Diomedea exulans, and Amsterdam al batross D. amsterdamensis in the Indian Ocean and their relationships with long-line fisheries: conservation implications. Biological Conservation 79: 257-270.

Zino, P. A. 1985. Pequeno apontamento histórico sobre a caça das cagarras na Selvagem Grande e desenvolvimentos recentes nesta ilha. Museu Municipal do Funchal, Bocagiana 84, 1-14. 